\title{
Characterization, quantitation and evolution of monoepoxy compounds formed in model systems of fatty acid methyl esters and monoacid triglycerides heated at high temperature
}

\author{
By O. Berdeaux, G. Márquez-Ruiz and M.C. Dobarganes*
}

Instituto de la Grasa (C.S.I.C.) Avda Padre García Tejero, 4. 41012 Sevilla, ESPAÑA.

\section{RESUMEN}

\begin{abstract}
Caracterización, cuantificación y evolución de monoepóxidos formados en sistemas modelo de ésteres metílicos de ácidos grasos y triglicéridos monoácidos, calentados a temperatura elevada.
\end{abstract}

En este estudio se identifican y cuantifican los compuestos epoxidados formados a partir de sistemas modelo de oleato y linoleato de metilo, trioleina y trilinoleina, calentados a $180^{\circ} \mathrm{C}$ durante 5,10 y 15 horas. La identificación se lleva a cabo mediante CG-EM en las muestras de ésteres metílicos antes y después de someter a hidrogenación y para su cuantificación se utilizan dos procedimientos de transesterificación en medio alcalino. La comparación de las cantidades obtenidas, antes y después de la derivatización de los sistemas modelo de ésteres metílicos, permitió deducir que la recuperación fue completa, obteniéndose también una excelente repetibilidad. Las cantidades de epóxidos encontradas fueron del mismo orden para ésteres metílicos y triglicéridos del mismo grado de insaturación, aunque la formación fue considerablemente mayor en los sistemas menos insaturados oleato de metilo y trioleina - posiblemente debido a la ausencia de dobles enlaces en la molécula, que limitaría su participación en posteriores reacciones. Por otra parte, independientemente del grado de insaturación del sustrato y del periodo de calentamiento, se encontraron cantidades significativamente más elevadas de los isómeros trans. Finalmente, es posible deducir, por comparación con la cantidad total de compuestos de degradación, que los epóxidos constituyen compuestos mayoritarios en las condiciones utilizadas.

PALABRAS-CLAVE: Ester metílico - Monoepóxido - Sistema modelo - Temperatura de fritura - Termoxidación - Triglicérido.

\section{SUMMARY}

Characterization, quantitation and evolution of monoepoxy compounds formed in model systems of fatty acid methyl esters and monoacid triglycerides heated at high temperature.

Monoepoxy compounds formed after heating methyl oleate and linoleate, triolein and trilinolein at $180^{\circ} \mathrm{C}$ for 5,10 and 15 hours, were characterized and quantitated after derivatization to fatty acid methyl esters by using two base-catalyzed procedures. Structures were identified by GC-MS before and after hydrogenation. A complete recovery of the epoxy compounds was obtained by comparing results from methyl oleate and linoleate before and after transesterification, and good repeatability was also attained. Similar amounts of epoxides were found for methyl esters and triglycerides of the same degree of unsaturation, although formation was considerably greater for the less unsaturated substrates, methyl oleate and triolein, possibly due to the absence of remaining double bonds in the molecule which would involve a lower tendency to participate in further reactions. On other hand, independently of the degree of unsaturation of the model systems and of the period of heating, significantly higher amounts of trans isomers were formed. Finally, from comparison between the amounts of epoxides and the level of polar fatty acids in samples, it was deduced that monoepoxy compounds were one of the major groups formed under the conditions used.

KEY-WORDS: Frying temperature - Methyl ester - Model system - Monoepoxy compound - Thermoxidation - Triglyceride.

\section{INTRODUCTION}

Degradation compounds formed at the high temperature of processes like frying have been extensively studied (Nawar, 1985; Dobarganes and Márquez Ruiz, 1996; Gasparoli, 1998). However, due to the complex mixture of compounds originated with different molecular weight and polarity, and to the variable alteration obtained depending of the variables applied, much work remains to be done to complete the present knowledge.

Total degradation compounds can be easily quantitated by means of adsorption chromatography (IUPAC, 1987). The determination, known as polar compounds, is the basis of the regulation in some European countries limiting the alteration of used frying fats for human consumption to $25 \%$ of polar compounds (Dobarganes and Márquez-Ruiz, 1998). Polar compounds include those formed through thermal, oxidative and hydrolytic reactions and it is also possible further quantitation of specific groups of degradation compounds, i.e., polymers, oxidized monomers, diglycerides and fatty acids, by exclusion chromatography, taking advantage of their different molecular weight (Dobarganes et al., 1988; Wolf et al., 1991; Márquez Ruiz et al., 1996). These determinations can be applied directly to the fats and oils or to their simpler derivatives, fatty acid methyl esters (MárquezRuiz et al., 1990).

Evaluation of used frying fats has shown that fatty acid dimers and polymers were predominantly formed at the limit for fat rejection. Concomitantly, substantial amounts of oxidized fatty acid monomers, 
normally around $30 \mathrm{mg} / \mathrm{g}$ oil, were found (MárquezRuiz et al., 1995a). Such oxidized monomeric fatty acids show high digestibility (Marquez.-Ruiz et al., 1992) and, consequently, more reseach is needed on the identification and nutritional significance of the specific structures included in this group.

Recent studies on the analysis of individual structures formed at high temperature (Capella, 1989; Christopoulou and Perkins, 1989; Gardner et al., 1992; Marquez-Ruiz et al., 1995b; Kamal Eldin et al., 1997) have been limited so far to qualitative evaluation and no quantitative results have been reported.

Considering that direct quantitation of specific structures is still a difficult task, the objective of this study was to quantitate epoxy compounds in model systems of triglycerides (TG) and fatty acid methyl esters (FAME) constituted by a single fatty acid, as a previous and necessary step to control artifact formation and/or losses during derivatization. Methyl linoleate and oleate as well as trilinolein and triolein were selected since linoleic and oleic acid are the most representative fatty acids undergoing alteration in frying fats and oils.

\section{MATERIALS AND METHODS}

Chemicals. Methyl linoleate (ML), methyl oleate $(\mathrm{ML})$, trilinolein (LLL) and triolein (OOO) were purchased from Nu-Chek-Prep.(Elysian, MIN, USA). Methyl trans- and cis- 9,10 epoxystearate were obtained from Sigma (St.Louis, MO, USA). Silica gel 60 for column chromatography was purchased from Merck (Darmstadt, Germany). Tetrahydrofuran was HPLC grade and other solvents were of analytical grade.

Samples. ML, MO, LLL and OOO were used as model systems.

Heating procedure. $2 \pm 0.01 \mathrm{~g}$ of sample were weighed directly into standard glass tubes $(20 \mathrm{~cm} x$ $12 \mathrm{~mm}$ i.d.). Tubes were introduced into a Rancimat vessel containing $8 \mathrm{~g}$ of glycerol to facilitate heat transfer, and inserted in the heating block previously heated at $180 \pm 1^{\circ} \mathrm{C}$. Vessels were left open during heating. Samples were heated for 5,10 , and 15 hours in duplicate and kept at $-20^{\circ} \mathrm{C}$ until analyses. This procedure was described in detail, including data repeatability, in a recent publication (Barrera et al., 1997).

Methylation procedures. A standard solution was prepared with a mixture of methyl tridecanoate (C13:0, $500 \mu \mathrm{g} / \mathrm{mL}$ ) and methyl pentadecanoate $(C 15: 0,500 \mu \mathrm{g} / \mathrm{mL})$ in diethyl ether or methyl-tertbutyl ether (MTBE). The following methylation procedures were applied:

a) Base-catalyzed transmethylation with $2 \mathrm{~N}$ potassium hydroxide in methanol at room temperature:
$100 \mathrm{mg}$ of sample were accurately weighed into a screwcapped centrifuge tube and dissolved in 0.5 $\mathrm{mL}$ of the standard solution in diethyl ether. Potassium hydroxide $(0.1 \mathrm{~mL}, 2 \mathrm{~N})$ in methanol was then added, the vial closed and shaken vigorously for 30 seconds. $1 \mathrm{~mL}$ of brine solution was added and the solution was neutralized with acetic acid. Mixture was shaken and centrifuged. $2 \mu \mathrm{L}$ from the organic layer were injected onto the gas-liquid chromatograph.

b) Base-catalyzed transmethylation with sodium methylate and MTBE at room temperature: $50 \mathrm{mg}$ of sample were accurately weighed into a screwcapped centrifuge tube of $5 \mathrm{~mL}$ and dissolved in $1 \mathrm{~mL}$ of the standard solution in MTBE. $0.5 \mathrm{~mL}$ of $0.2 \mathrm{~N}$ sodium methylate in methanol solution was added, the vial closed, shaken for $1 \mathrm{~min}$ and left for 2 min at room temperature. $0.1 \mathrm{~mL}$ of $1 \mathrm{~N} \mathrm{H}_{2} \mathrm{SO}_{4}$ in water solution was then added and the mixture was shaken for a few seconds. The mixture was diluted with $1.5 \mathrm{~mL}$ of water, shaken for 10 seconds and centrifuged. $2 \mu \mathrm{L}$ from the organic layer were injected directly onto the gas-liquid chromatograph (Cecchi et al., 1985).

Gas-liquid chromatography (GC). FAMEs were analyzed by GC using a HP 6890 chromatograph on a HP innowax capillary column: $30 \mathrm{~m} \times 0.25 \mathrm{~mm}$ i.d., film thickness $0.25 \mu \mathrm{m}$ (Hewlett Packard, USA) under the following temperature programme: $90^{\circ} \mathrm{C}$ (2min), $4^{\circ} \mathrm{C} / \mathrm{min} ; 240^{\circ} \mathrm{C}(25 \mathrm{~min})$. Samples were introduced to the column via a split injector (split ratio $1: 40$ ) at $250^{\circ} \mathrm{C}$ and the flow rate of hydrogen, used as carrier gas, was $1 \mathrm{~mL} / \mathrm{min}$. Temperature of both split injector and flame ionization detector was $250^{\circ} \mathrm{C}$. Quantitative data for epoxy FAME were obtained by applying accurate relative response factors. Identical responses were found for the methyl trans- and cis9,10 epoxystearate used for calibration curve. Taking 1.00 as response factor for methyl tridecanoate and methyl pentadecanoate, the average correction factor calculated for either methyl trans- or cis-9, 10 epoxystearate was 1.19.

Gas-liquid chromatography - mass spectrometry (GC-MS). GC-MS analysis was performed with a Finnigan MAT 95's double focusing mass spectrometer (Finnigan, Bremen, Germany) operating in the electron ionization mode. Electron energy was 70 $\mathrm{eV}$, multiplier voltage $1500 \mathrm{~V}$, source temperature $200^{\circ} \mathrm{C}$ and transfer line $250^{\circ} \mathrm{C}$. Spectral data were acquired over a mass range of 28-600 amu at a scan rate of $1 \mathrm{~s} / \mathrm{scan}$, Chromatographic conditions were the same as those used for GC analysis.

Separation of non polar and polar compounds by adsorption chromatography. Non polar and polar fractions were separated from $1 \mathrm{~g}$ of sample by silica column chromatography $\left(20 \mathrm{~g}\right.$ silica- $\mathrm{H}_{2} \mathrm{O}, 95: 5$ (w/w)). Non polar fraction containing unoxidized TG or FAME was eluted with $150 \mathrm{~mL}$ of $\mathrm{n}$-hexanediethylether $(90: 10, \mathrm{v} / \mathrm{v})$ for $\mathrm{OOO}$ and LLL (Dobarganes 
et al., 1988) and $150 \mathrm{~mL}$ of $\mathrm{n}$-hexane-diethylether (95:5, v/v) for ML and MO (Dobarganes et al., 1984). A second fraction, comprised of total polar compounds, was eluted with $150 \mathrm{~mL}$ of diethylether. Efficiency of the separation by adsorption chromatography was checked by thin layer chromatography (TLC) using hexane-diethylether- acetic acid (80:20:1, v/v/v) for development of plates and exposure to iodine vapour to reveal the spots. After evaporation of solvents, both fractions were weighed and dissolved in diisopropyl ether until further analysis.

High-performance size exclusion chromatography (HPSEC) of the polar and non polar fraction. The polar and non polar fractions obtained from the two previous steps were dissolved in diisopropyl ether to a concentration of $25 \mathrm{mg} / \mathrm{mL}$ for analysis by HPSEC in a Waters 510 pump with $10-\mu \mathrm{L}$ sample loop (Waters, Milford, MA, USA). A HP 1037 refractive index detector and an HP $3392 \mathrm{~A}$ integrator (Hewlett-Packard, Avondale, PA, USA) were used. The separation was performed on two 100 and $500 \AA$ Ultrastyragel columns $(25 \mathrm{~cm} \times 0.77 \mathrm{~cm}$ i.d. $)$ packed with porous, highly cross linked styrene-divinylbenzene copolymer (film thickness $10 \mu \mathrm{m}$, Waters) connected in series, with tetrahydrofuran $(1 \mathrm{~mL} / \mathrm{min})$ as the mobile phase (Dobarganes et al., 1988).

\section{RESULTS AND DISCUSSION}

Figures 1 and 2 show reconstructed ion chromatograms for $M L$ and $M O$, respectively, after heating for 15 hours at $180^{\circ} \mathrm{C}$. The main advantage of FAME model systems is that analysis is carried out directly on the heated sample, thus overcoming any possible artifact formation during transesterification of TG. The numbered peaks, identified as monoepoxy compounds, seemed to be major degradation compounds as the only peak with higher area in all the chromatographic analyses corresponded to the unoxidized substrate, either in heated ML or MO. Monoepoxy-compounds were identified by GC-MS with the help of the methyl trans-and cis-9,10 epoxystearate standards, whose spectra and retention times were identical to those present in heated methyl oleate, thus denoting formation of the epoxide at the site of the double bond. In the case of ML, the presence of four peaks of molecular mass $16 \mathrm{u}$ larger than unoxidized ML also indicated that the epoxide ring was formed by replacing a site of unsaturation and, thus, the compounds were methyl epoxyoleates. Tentatively, they were assigned as indicated in Figure 1, based on their saturated counterparts obtained after hydrogenation. Figure 3 shows the ion chromatogram for the hydrogenated heated methyl linoleate where two of the peaks corresponded, as expected, to methyl trans-and cis- 9,10 epoxyestearate and the other two were assigned as trans- and cis-12,13 epoxystearate.

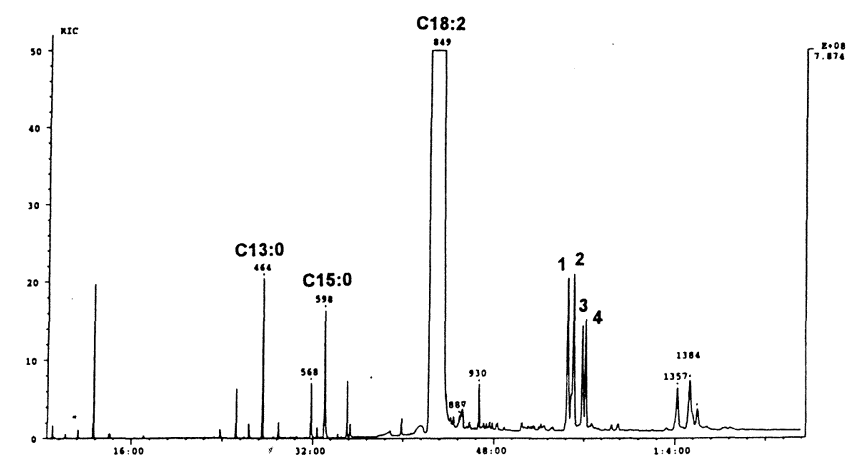

Figure 1

Reconstructed ion chromatogram of thermoxidized methyl linoleate. Peak assignments: 1 , methyl trans-12,13 epoxyoleate; 2 , methyl trans-9,10 epoxyoleate; 3 , methyl cis-12,13 epoxyoleate and 4, methyl cis-9,10 epoxyoleate

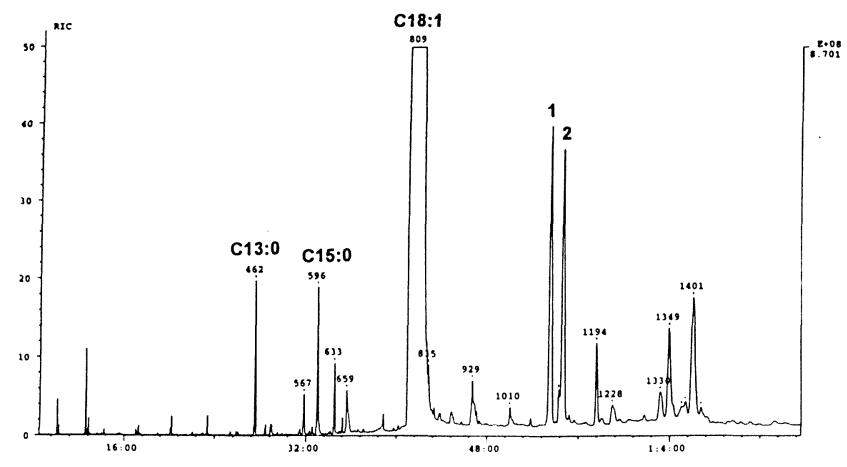

Figure 2

Reconstructed ion chromatogram of thermoxidized methyl oleate. Peak assignments: 1 , methyl trans-9,10 epoxystearate and 2, methyl cis-9,10 epoxystearate

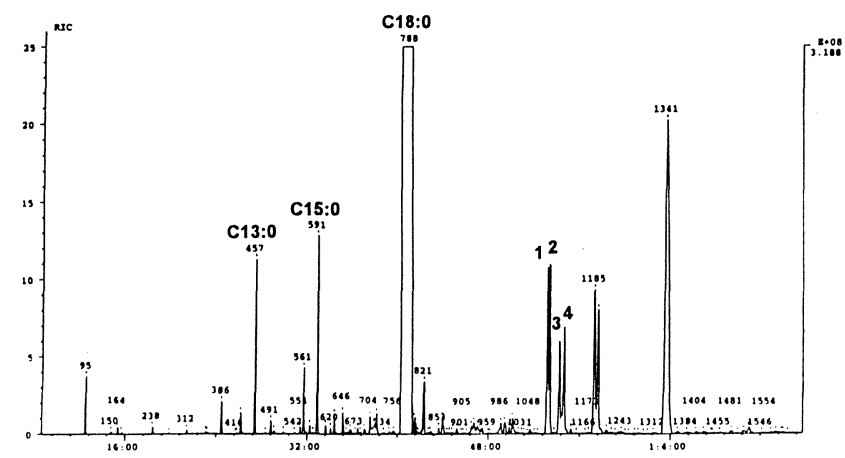

Figure 3

Reconstructed ion chromatogram of hydrogenated thermoxidized methyl linoleate. Peak assignments:1, methyl trans-12,13 epoxystearate; 2 , methyl trans- 9,10 epoxystearate; 3 , methyl cis-12,13 epoxystearate and 4, methyl cis-9,10 epoxystearate 
For quantitative purposes, base-catalyzed transmethylation methods were selected as it is well known that acid-catalyzed methanolysis results in epoxy ring opening to afford hydroxy methoxy esters (Kleiman et al., 1973; Bryant et al., 1992). On the other hand, methodologies at room temperature and extraction with polar solvents were preferred in order to avoid losses of volatiles or other polar compounds in the heated samples.

Table I and II show quantitative results for heated $M O$ and $M L$, respectively, after heating for different periods of time and analyzed in triplicate by GC. Results correspond to the direct analysis of the heated samples (Control) and after transesterification by using $2 \mathrm{~N}$ potassium hydroxide $(\mathrm{KOH})$ or sodium methoxide $\left(\mathrm{CH}_{3} \mathrm{ONa}\right)$. As can be observed, not only repeatability was excellent but also comparison of the results before and after transesterification demonstrated total recovery and absence of artifacts under the conditions used. On the other hand, independently of the period of heating and of the methyl ester, the amounts of trans isomers were significantly higher than those of cis isomers. Also, similar levels of positional isomers, i.e., epoxy 9, 10 and epoxy 12,13 , were found in the case of ML.

Table I

Quantitation of methyl monoepoxyoleates ( $\mathrm{mg} / \mathrm{g}$ of oil) in model systems of methyl linoleate heated at $180^{\circ} \mathrm{C}$ for 5,10 and $15 \mathrm{~h}$, before and after $\mathrm{KOH}$ or $\mathrm{CH}_{3} \mathrm{ONa}$ catalyzed transmethylation

\begin{tabular}{|c|c|c|c|c|c|c|c|c|c|}
\hline & \multicolumn{3}{|c|}{ Control } & \multicolumn{3}{|c|}{$\mathrm{KOH}$} & \multicolumn{3}{|c|}{$\mathrm{CH}_{3} \mathrm{ONa}$} \\
\hline & $5 \mathrm{~h}$ & $10 \mathrm{~h}$ & $15 \mathrm{~h}$ & $5 \mathrm{~h}$ & $10 \mathrm{~h}$ & $15 \mathrm{~h}$ & $5 \mathrm{~h}$ & $10 \mathrm{~h}$ & $15 \mathrm{~h}$ \\
\hline Trans-9,10 & $2.8 \pm 0.31$ & $4.0 \pm 0.33$ & $5.9 \pm 1.15$ & $2.3 \pm 0.33$ & $4.1 \pm 0.25$ & $6.6 \pm 1.08$ & $2.5 \pm 0.29$ & $3.6 \pm 0.10$ & $6.0 \pm 0.17$ \\
\hline Trans-12,13 & $3.7 \pm 0.65$ & $4.4 \pm 0.76$ & $6.9 \pm 1.18$ & $3.1 \pm 1.06$ & $4.7 \pm 0.58$ & $5.6 \pm 0.68$ & $3.9 \pm 0.10$ & $4.6 \pm 0.61$ & $6.9 \pm 0.44$ \\
\hline Cis- 9,10 & $1: 4 \pm 0.47$ & $2.5 \pm 0.84$ & $3.1 \pm 0.16$ & $1.3 \pm 0.14$ & $2.3 \pm 0.08$ & $3.3 \pm 0.37$ & $1.2 \pm 0.01$ & $1.9 \pm 0.02$ & $3.2 \pm 0.17$ \\
\hline Cis-12,13 & $1.3 \pm 0.18$ & $2.2 \pm 0.24$ & $3.2 \pm 0.21$ & $1.3 \pm 0.02$ & $2.4 \pm 0.08$ & $2.9 \pm 0.34$ & $1.1 \pm 0.01$ & $1.9 \pm 0.02$ & $3.2 \pm 0.17$ \\
\hline Total & $9.2 \pm 0.16$ & $13.1 \pm 0.47$ & $19.1 \pm 2.49$ & $8.0 \pm 1.46$ & $13.5 \pm 0.68$ & $18.4 \pm 2.04$ & $8.7 \pm 0.37$ & $12.0 \pm 0.74$ & $19.3 \pm 0.74$ \\
\hline
\end{tabular}

Values are means \pm standard deviation $(n=3)$

Table II

Quantitation of methyl monoepoxystearates $(\mathrm{mg} / \mathrm{g}$ of oil) in model systems of methyl oleate heated at $180^{\circ} \mathrm{C}$ for 5,10 and $15 \mathrm{~h}$, before and after $\mathrm{KOH}$ or $\mathrm{CH}_{3} \mathrm{ONa}$ catalyzed transmethylation

\begin{tabular}{|c|c|c|c|c|c|c|c|c|c|}
\hline & \multicolumn{3}{|c|}{ Control } & \multicolumn{3}{|c|}{$\mathrm{KOH}$} & \multicolumn{3}{|c|}{$\mathrm{CH}_{3} \mathrm{ONa}$} \\
\hline & $5 \mathrm{~h}$ & $10 \mathrm{~h}$ & $15 \mathrm{~h}$ & $5 \mathrm{~h}$ & $10 \mathrm{~h}$ & $15 \mathrm{~h}$ & $5 \mathrm{~h}$ & $10 \mathrm{~h}$ & $15 \mathrm{~h}$ \\
\hline Trans- 9,10 & $9.7 \pm 0.21$ & $11.3 \pm 0.99$ & $20.3 \pm 1.85$ & $9.4 \pm 0.06$ & $10.7 \pm 0.09$ & $17.9 \pm 0.65$ & $9.4 \pm 0.08$ & $10.5 \pm 0.23$ & $18.4 \pm 0.64$ \\
\hline Cis- 9,10 & $4.5 \pm 0.24$ & $8.9 \pm 0.66$ & $14.9 \pm 1.08$ & $4.3 \pm 0.04$ & $9.3 \pm 0.11$ & $13.2 \pm 0.40$ & $4.5 \pm 0.08$ & $9.1 \pm 0.35$ & $13.9 \pm 0.42$ \\
\hline Total & $14.2 \pm 0.2$ & $20.2 \pm 0.41$ & $35.2 \pm 2.53$ & $13.7 \pm 0.10$ & $20.0 \pm 0.20$ & $31.1 \pm 1.0$ & $13.8 \pm 0.16$ & $19.6 \pm 0.57$ & $32.3 \pm 1.06$ \\
\hline
\end{tabular}

Values are means \pm standard deviation $(n=3)$

The quantitative importance of monoepoxy compounds can be established by comparing their amounts with those found for total polar or altered FAME and, particularly, for the fraction eluting by GC under the conditions used, i.e., polar monomeric FAME. Table III shows the results obtained for total polar FAME, and their distribution in polymeric and monomeric FAME in the different samples prepared in duplicate. Analyses were carried out by adsorption and exclusion chromatographies as detailed in the experimental part. As can be observed, in spite of the different unsaturation degree of $M O$ and $M L$, the amounts of total altered FAME were of the same order for equal periods of heating and the main difference between the two model systems was the higher tendency for polymerization of $\mathrm{ML}$, the most unsaturated FAME.

From the mean values for monoepoxyesters (Tables I and II), total polar FAME and polar monomeric FAME (Table III), the contribution of monoepoxy compounds was calculated and the data included in Table IV. As can be observed, epoxyesters constituted a very high percentage of the polar monomeric fraction (between 25 and 50\%) and even of the total 
polar FAME, considering that hundreds of new compounds are expected to be formed. On the other hand, the higher quantitative importance of monoepoxy compounds from $\mathrm{MO}$ as compared to those from $\mathrm{ML}$ was also remarkable. This fact can be explained by the lower tendency of the epoxycompounds without remaining double bonds to participate in further reactions. Thus, the occurrence of epoxy structures in ML samples would be necessarily greater than that reflected in the monoepoxy compounds levels, on account of those containing additional oxygenated functions and the epoxy functions included in polymerization products.

Table III

Total polar compounds (wt\% on oil), and polar compound distribution $(\mathrm{mg} / \mathrm{g}$ oil) in model systems of methyl oleate (MO) and methyl linoleate $(\mathrm{ML})$ heated at $180^{\circ} \mathrm{C}$ for 5,10 and $15 \mathrm{~h}$

\begin{tabular}{ccccc}
\hline \multirow{2}{*}{ Sample } & $\begin{array}{c}\text { Heating } \\
\text { period }(\mathrm{h})\end{array}$ & Total & \multicolumn{2}{c}{ Polar compounds } \\
\cline { 3 - 5 } & & & \multicolumn{2}{c}{ Distribution } \\
\cline { 3 - 5 } & 5 & $8.9 \pm 1.34$ & $63 \pm 9.8$ & $26 \pm 3.6$ \\
& 10 & $17.8 \pm 0.21$ & $116 \pm 8.9$ & $67 \pm 0.3$ \\
MO & 15 & $23.6 \pm 1.70$ & $148 \pm 10.6$ & $87 \pm 16.3$ \\
& 5 & $10.0 \pm 0.42$ & $68 \pm 1.0$ & $32 \pm 3.1$ \\
& 10 & $17.2 \pm 0.35$ & $124 \pm 1.9$ & $48 \pm 2.0$ \\
ML & 15 & $26.2 \pm 0.42$ & $193 \pm 8.8$ & $69 \pm 12.7$ \\
\hline
\end{tabular}

FAP, fatty acid polymers; $F A D$, fatty acid dimers, and OXFAM, oxidized fatty acid monomers. Values are means \pm standard deviation $(n=2)$
Table IV

Quantitative contribution of monoepoxy compounds to total polar fatty acid methyl esters and to its monomeric fraction

\begin{tabular}{cccc}
\hline Sample & $\begin{array}{c}\text { Heating } \\
\text { period }(\mathrm{h})\end{array}$ & $\begin{array}{c}\text { Epoxy FAME } \\
\text { (\% on total polar FAME) }\end{array}$ & $\begin{array}{c}\text { Epoxy FAME } \\
\text { (\% on polar monomeric FAME) }\end{array}$ \\
\hline \multirow{2}{*}{ ML } & 5 & 8.3 & 26.1 \\
& 10 & 7.6 & 27.1 \\
& 15 & 7.3 & 27.6 \\
\multirow{4}{*}{ MO } & 5 & 16.0 & 53.8 \\
& 10 & 11.3 & 30.0 \\
& 15 & 14.9 & 40.2 \\
\hline
\end{tabular}

After checking recovery, repeatability and absence of artifact formation for the compounds of interest in FAME model systems, similar experiments were carried out with monoacid triglycerides, which otherwise have necessarily to be transesterified prior to GC analysis. Regardless of the procedure used, transmethylation of the samples was complete, as no partial glycerides were detected by TLC. Quantitative results for monoepoxy compounds are shown in Tables $\mathrm{V}$ and $\mathrm{VI}$ for LLL and $\mathrm{OOO}$, respectively. Total amounts found were of the same order than those obtained for their corresponding FAME and trans isomers were also preferentially formed.

Table V

Quantitation of methyl monoepoxyoleates $(\mathrm{mg} / \mathrm{g}$ of oil) in model systems of trilinolein heated at $180^{\circ} \mathrm{C}$ for 5,10 and $15 \mathrm{~h}$ after $\mathrm{KOH}$ or $\mathrm{CH}_{3} \mathrm{ON} \mathrm{N}_{\mathrm{a}}$ catalyzed transmethylation

\begin{tabular}{|c|c|c|c|c|c|c|}
\hline & \multicolumn{3}{|c|}{$\mathrm{KOH}$} & \multicolumn{3}{|c|}{$\mathrm{CH}_{3} \mathrm{ON}_{\mathrm{a}}$} \\
\hline & $5 h$ & $10 \mathrm{~h}$ & $15 \mathrm{~h}$ & $5 h$ & $10 \mathrm{~h}$ & $15 \mathrm{~h}$ \\
\hline Trans-9,10 & $2.0 \pm 0.21$ & $5.0 \pm 0.41$ & $7.1 \pm 0.55$ & $2.1 \pm 0.11$ & $5.2 \pm 0.29$ & $6.3 \pm 0.16$ \\
\hline Trans-12,13 & $2.7 \pm 0.56$ & $5.5 \pm 0.59$ & $6.5 \pm 0.74$ & $2.9 \pm 0.36$ & $5.7 \pm 0.16$ & $6.4 \pm 0.12$ \\
\hline Cis-9,10 & $1.1 \pm 0.10$ & $2.3 \pm 0.17$ & $3.3 \pm 0.39$ & $1.0 \pm 0.01$ & $2.5 \pm 0.14$ & $2.8 \pm 0.04$ \\
\hline Cis-12,13 & $1.1 \pm 0.07$ & $2.5 \pm 0.13$ & $3.2 \pm 0.53$ & $0.9 \pm 0.01$ & $2.4 \pm 0.11$ & $2.8 \pm 0.06$ \\
\hline Total & $6.8 \pm 0.72$ & $15.3 \pm 0.46$ & $20.1 \pm 1.6$ & $6.9 \pm 0.23$ & $15.8 \pm 0.69$ & $18.3 \pm 0.21$ \\
\hline
\end{tabular}

Values are means \pm standard deviation $(n=3)$.

Table VI

Quantitation of methyl monoepoxystearates ( $\mathrm{mg} / \mathrm{g}$ of oil) in model systems of triolein heated at $180^{\circ} \mathrm{C}$ for 5,10 and $15 \mathrm{~h}$ after $\mathrm{KOH}$ or $\mathrm{CH}_{3} \mathrm{ON}_{\mathrm{a}}$ catalyzed transmethylation

\begin{tabular}{|c|c|c|c|c|c|c|}
\hline & \multicolumn{3}{|c|}{$\mathrm{KOH}$} & \multicolumn{3}{|c|}{$\mathrm{CH}_{3} \mathrm{ON}_{\mathrm{a}}$} \\
\hline & $5 \mathrm{~h}$ & $10 \mathrm{~h}$ & $15 \mathrm{~h}$ & $5 \mathrm{~h}$ & $10 \mathrm{~h}$ & $15 \mathrm{~h}$ \\
\hline Trans-9,10 & $9.8 \pm 0.44$ & $15.8 \pm 2.07$ & $25.0 \pm 0.21$ & $9.8 \pm 0.07$ & $17.4 \pm 0.03$ & $26.2 \pm 0.92$ \\
\hline Cis-9,10 & $3.6 \pm 0.33$ & $6.0 \pm 0.35$ & $9.4 \pm 0.82$ & $3.5 \pm 0.11$ & $6.3 \pm 0.18$ & $9.5 \pm 0.17$ \\
\hline Total & $13.4 \pm 0.77$ & $21.8 \pm 2.41$ & $34.4 \pm 1.01$ & $13.3 \pm 0.15$ & $23.7 \pm 0.1$ & $35.7 \pm 1.08$ \\
\hline
\end{tabular}

Values are means \pm standard deviation $(n=3)$. 
It is important to note that TG are the predominant structures in fats and oils and hence the great interest of the results obtained on TG model systems. Levels of total polar compounds (Table VII) were here, as expected, much higher than those of FAME model systems (Table III). In fact, polar compounds in FAME model systems are exclusively modified, altered FAME, while polar compounds in TG model systems include TG containing one to three modified fatty acyl groups and therefore a considerable number of unoxidized fatty acyl groups. Results in Table VII also showed, as occurred for ML vs. MO, a higher tendency to polymerization of LLL vs. OOO.

As can be observed, only the samples heated for 5 hours had polar compound levels compatible with the established regulations on frying fats and oils (below 25\%), although it is not strange to find used frying fats with polar compounds percentages as high as those found for LLL heated for 15 hours (Gertz, 1986; Sebedio, 1987; Dobarganes and Márquez-Ruiz, 1995). Thus, considering that linoleic and oleic acids are the most representative fatty acids undergoing degradation during the frying process, the amounts of monoepoxides found in $\mathrm{OOO}$ and LLL should not be far different from those present in frying fats and oils. Using the methodology described here, we are currently quantitating epoxides in olive and sunflower oils subjected to thermoxidation under the conditions used in this study, and in real used frying fats and oils from frying food outlets. Results will be shortly communicated.

Table VII

Total polar compounds (wt\% on oil), and polar compound distribution ( $\mathrm{mg} / \mathrm{g}$ oil) in model systems of triolein (OOO) and trilinolein (LLL) heated at $180^{\circ} \mathrm{C}$ for 5,10 and $15 \mathrm{~h}$

\begin{tabular}{ccccc}
\hline \multirow{2}{*}{ Sample } & $\begin{array}{c}\text { Heating } \\
\text { period }(\mathrm{h})\end{array}$ & Total & \multicolumn{2}{c}{ Polar compounds } \\
\cline { 3 - 5 } & & & $156 \pm 9.7$ & $76 \pm 5.8$ \\
\cline { 3 - 5 } & & $21.7 \pm 0.77$ & FAstribution \\
\hline \multirow{3}{*}{ LLL } & 10 & $41.5 \pm 1.20$ & $285 \pm 10.3$ & $29 \pm 0.1$ \\
& 15 & $53.2 \pm 0.07$ & $378 \pm 3.9$ & $52 \pm 0.9$ \\
& 5 & $20.2 \pm 0.35$ & $95 \pm 9.6$ & $100 \pm 5.4$ \\
\multirow{3}{*}{000} & 10 & $32.8 \pm 0.57$ & $158 \pm 2.1$ & $160 \pm 10.3$ \\
& 15 & $42.7 \pm 0.85$ & $210 \pm 12.4$ & $207 \pm 2.1$ \\
\hline
\end{tabular}

TGP, triglyceride polymers; TGD, triglyceride dimers; OxTGM, oxidized triglyceride monomers. Values are means \pm standard deviation $(n=2)$.

\section{ACKNOWLEDGEMENTS}

O. Berdeaux was supported by a grant from EC (Contract FAIR-CT97-5016). This work was funded in part by CICYT (Project ALI 98-0884). The authors thank J.J. Ríos for GLC-MS analyses and $M$. Giménez for assistance.

\section{REFERENCES}

Barrera-Arellano, D., Márquez-Ruiz, G. and Dobarganes, M.C. (1997). - «A simple procedure to evaluate the performance of fats and oils at frying temperatures".Grasas y Aceites 48, 231-235.

Bryant, K.A.A., Nwaonicha, Ch.P., Anderson, M.A. and Ayorinde, F.O. (1992). - «Acid-catalyzed alcoholysis of vernonia galamensis oil».-J. Am. Oil Chem. Soc. 69, 1023-1026.

Capella, P. (1989)._- «Les produits de l'évolution des hydroperoxydes".-Rev. Franc. Corps Gras 36, 313-323.

Cecchi, G., Biasini, S. and Castano, J. (1985)."Méthanolyse rapide des huiles en solvant».-Rev. Franc. Corps Gras 32,163-164.

Christopoulou, C.N. and Perkins, E.G. (1989)."Chromatographic studies on fatty acid dimers: Gas-liquid chromatography, high-performance liquid chromatography and thin-layer chromatography».-J. Am. Oil Chem. Soc. 66, 1353-1359.

Dobarganes, M.C., Pérez-Camino, M.C. and Gutiérrez González-Quijano, R. (1984).—-Métodos analíticos de aplicación en grasas calentadas. I. Determinación de ésteres metílicos no alterados".-Grasas y Aceites $35,172-177$.

Dobarganes, M.C., Pérez-Camino, M.C. and MárquezRuiz, G. (1988).—-High performance size exclusion chromatography of polar compounds in heated and non-heated fats".-Fat Sci. Technol. 90, 308-311.

Dobarganes, M.C. and Márquez-Ruiz, G. (1995)."Calidad de las grasas de fritura en el sector de restauración de Andalucía».-Grasas y Aceites 46, 115-120.

Dobarganes, M.C. and Márquez-Ruiz, G. (1996)."Dimeric and higher oligomeric triglycerides" in: «Deep fying: chemistry, nutrition and practical applications".-AOCS Press, p. 89.- E.G. Perkins and M.D. Erickson (Eds.).-Champaign, IL.

Dobarganes, M.C. and Márquez-Ruiz, G. (1998).«Regulation of used frying fats and validity of quick tests for discarding the fats".-Grasas y Aceites 49, 331-335.

Gardner, D.R., Sanders, R.A., Henry, D.E., Tallmadge, D.H. and Wharton, H.W. (1992).- «Characterization of used frying oils. Part 1: Isolation and identification of compound classes". J. Am. Oil Chem. Soc. 69, 499-508.

Gasparoli, A.(1998).- «The formation of new compounds".-Grasas y Aceites 49, 303-309.

Gertz, C. (1986).- «Chromatographische Methoden bei der Untersuchung von Fritierfetten».- Fette Seifen Anstrichm. 88, 475-480.

IUPAC (1987). - «Standard Method 2.507: Determination of polar compounds in frying fats" in: Standard Methods for the Analysis of Oils, Fats and Derivatives, 7th Edition, ed. Intemational Union of Pure and Applied Chemistry. Oxford, England: Blackwell.

Kamal-Eldin, A., Márquez-Ruiz, G., Dobarganes, M.C. and Appelqvist, L.-A. (1997). - «Characterisation of aldehydic acids in used and unused frying oils".-J. Chromatogr. 776, 245-254.

Kleiman, R. and Spencer, G.F. (1973).- "Gas chromatographyMass spectrometry of methyl esters of unsaturated oxygenated fatty acids".-J. Am. Oil Chem. Soc. 50, 31-38.

Márquez-Ruiz, G., Pérez-Camino, M.C. and Dobarganes, M.C. (1990).- -Combination of adsorption and size-exclusion chromatography for the determination of fatty acid monomers, dimers and polymers".-J. Chromatogr. 514, 37-44. 
Márquez-Ruiz, G., Pérez-Camino, M.C. and Dobarganes, M.C. (1992).- "Digestibility of fatty acid monomers, dimers and polymers in the rat".-J. Am. Oil Chem. Soc. 76, 930-934.

Márquez-Ruiz, G., Tasioula-Margari, M., and Dobarganes, M.C. (1995a).- "Quantitation and distribution of altered fatty acids in frying fats».-J. Am. Oil Chem. Soc. 72, 1171-1176.

Márquez-Ruiz, G., Ríos, J.J., Tasioula-Margari, M. and Dobarganes, M.C. (1995b).— -Quantitation of oxidized fatty acids in frying fats and identification of major structures by GLC-MS".-Proceedings of EURO FOOD CHEM VIII, September 18-20, 1995, Vienna, Austria, p. 430-433.

Márquez-Ruiz, G., Jorge, N., Martín-Polvillo, M. and Dobarganes, M.C. (1996).-«Rapid, quantitative detemination of polar compounds in fats and oils by solid-phase extraction and exclusion chromatography using monostearin as internal standard".-J. Chromatogr. 749, 55-60.

Nawar, W.W. (1985).- «Chemistry of thermal oxidation in lipids" in "Flavor Chemistry of Fats and Oils".AOCS, p. 39.-D.B. Min and T.H. Smouse (Eds). Champaign, IL.

Sebedio, J.L., Grandgirard, A., Septier, C. and Prevost, J. (1987)._- «tat d'altération de quelques huiles de friture prélevées en restauration".-Rev. Franc. Corps Gras 34, 15-18.

Wolff, I.P., Mordret, F.X. and Dieffenbacher, A. (1991)."Determination of polymerized triglycerides in oils and fats by high-performance liquid chromatography".Pure Appl. Chem. 63, 1163-1171.

Recibido : Mayo 1998 Aceptado : Junio 1998 